\title{
III. Experiments to determine the quantity of tanning principle and gallic acid contained in the bark of various trees
}

\section{George Biggin Esq.}

To cite this article: George Biggin Esq. (1800) III. Experiments to determine the quantity of tanning principle and gallic acid contained in the bark of various trees, Philosophical Magazine Series 1, 5:20, 321-325, DOI: 10.1080/14786440008677163

To link to this article: http://dx.doi.org/10.1080/14786440008677163

曲 Published online: 25 Jan 2010.

Submit your article to this journal $\pi$

Џll Article views: 3

Q View related articles 5 
one day find, in thefe ravaged countries, objects worthy of their refearches. Fragments of the minerals and earths of Tunguragua are about to be tranfported to Spain: but it is not in fuch fragments that we ought to fearch for the caufe of thefe furprifing phenomena ; we muft vifit the country itfelf, where this confliet of the elements took place, and where the ruins it occafioned are ftill to be feen *.

III. Experiments to determine the Quantity of Tanning Principle and Gallic Acid contained in the Bark of various Trees. By George Biggin, Efq. $\uparrow$

$\mathrm{T}$

$\mathrm{HE}$ bark of trees contains the aftringent principle called gallic acid, and alfo that principle which has a peculiar affinity to the matter of $f \mathrm{kin}$, and which, from the ufe to which it is applied, is called the tanning principle. But, in the prefent mode of tanning, bark is applied in ma/s to the fkins; confequently, botb principles are applied. It remains for examination, whether both principles are ufeful in the procefs of tanning; for, if they are not both ufeful, probably one is detrimental.

To a nobleman, whofe zeal on every occafion by which the fciences or arts may receive illuftration or improvement, is eminently confpicious, and to whofe public energy, as well as private friendhip, I feel myfelf much indebted, to his Grace the Duke of Bedford, I owe the means of profecuting fome experiments on this fubject. His Grace, by collecting a variety of barks, at Woburn, gave me an opportunity of making fome experiments to afcertain the quantity of tanning principle and gallic acid each bark contained. For that purpofe I made ufe of the following methods, according to the principles laid down by $M$. Seguin :-

By diffolving an ounce of common glue in two pounds of boiling water, I procured a mucilaginous liquor, which, as it contains the matter of fkin in folution, is a teft for the

* The volcano of Tunguragua occafioned an earthquake in 1557 .

+ From the Pbiloopbical Tranjaltions of the Royal Socicty of London.

VoL. V.

$\mathrm{T} \mathbf{t}$

tanning 
tanning principle. By a faturated folution of fulphat of iron, I obtained a teft for the gallic acid.

I then took one pound of the bark I meant to try, ground as for the ufe of tanners, and divided it into five parts, each part being put into an earthen veffel. To one part of this bark I added two pounds of water, and infufed them for one hour. Thus I procured an infufion of bark, which I poured on the fecond part of the bark, and this ftrengthened infufion again on the third part, and fo on to the fifth. But, as a certain portion of the infufion will remain attached to the wood of the bark after the infufion is poured or drawn off, I added a third pound of water to the firtt part, and then followed up the infufion on the feveral parts till the three pounds of water, or fo much of them as could be feparated from the bark, were united in the fifth veffel; from which I generally obtained about one pint of ftrong infufion of bark *.

To a certain quantity of this infufion, 1 added a given meafure of the folution of glue, which formed an immediate precipitate, that may be feparated from the infufion by filtering paper. When dried, it is a fubftance formed by the chemical unien of the matter of $f$ kin with the tanning principle, and is, in fact, a powder of leather. By faturating the infufion with the folution of glue, the whole of the tanning principle may be feparated by precipitation.

\section{For the Gallic Acid.}

To the pound of bark left in the earthen veffels, and al ready deprived of its tanning principle by thefe quick infufions, I added a given quantity of water, to procure a ftrong infufion of the gallic acid, which requires a longer time, (fay forty-eight hours.) This infufion, when obtained puret, affords little figns of the prefence of the tanning principle,

* The fpecific gravity of this infufion was afcertained by an hydrometer whofe gradations are invelte to thofe of a fpirit hydromcter.

+ It is hardly poffible, from the intimate connection of the two principles, to feparate them entirely by infufion: in the infution of tanning principle, there will always exift a little gallic acid; and, in an infufion of gatlic acid, a little tanning principle will commonly be prefent, unlefs the infufion of gallic acid is viry weak, and procured by a third or fourth watering. 
when tried by the teft of the folution of glue; but, with the folution of fulphat of iron, it gives a ftrong black colour, (the common black dye,) which differs in denfity according to the quality of the bark: this may be further proved, by boiling a $\mathrm{k}$ kain of worfted in the dye, by which the gradations of colour will be very perceptibly demonftrated.

Having thus obtained a point of comparifon; by making a fimilar infufion, under fimilar circumftances, of any bark, or vegetable fubftance, and paying ftrict attention to the fpecific gravity of the infufion, the quantity of precipitate of leather, and the denfity of colour produced by given quantities of one or the other teft, the refult will be, a comparative ftatement of the refpective powers of any bark, or vegetable fubftance. This comparative ftatement I conceive to be fufficient for all commercial purpofes.

As oak bark is the ufual fubtance employed in the trade of tanning; if a quantity of tanning principle is found to be contained in any other bark or vegetable, the commercial utility of that bark or vegetable may be determined, by comparing its quantity of tanning principle and price with thofe of oak bark.

For an accurate chemical analyfis, I have tried a variety of. acids, and fimple and compound affinities; and, having purfued the above experiments at the fame time that I was employed on fome in dyeing, I found the muriat of tin (the method of ufing which is defcribed by $\mathrm{Mr}$. Prouft in the Annales de Cbimie,) very onvenient. A folution of it being added to the infufion of bark, forms a precipitate with the tanning principle, leaving the gallic acid fufpended : the precipitate is of a fawn colqur, and is compofed of tanning principle and oxydated tin.

By thefe means I have been enabled to form a comparative fcale of barks; which, however, I do not produce as accurate. Oak bark, in its prefent ftate, as procured for commercial purpofes, differs very much in quality, from accidental circumftances: the feafon of the year in which it is collected occafions a ftill more important difference, confequently the fcale now produced muft be very. imperfect; but I am of opinion, that, by the purfuits of fcientific men, 
324 Tanning Principle and Gallic Acid in Barks.

who may be inclined to invertigate this fubject more fully, a very accurate fcale may hereafter be formed.

In the following fcale, I have taken Sumach as the moft powerful in the comparative ftatement; leaving, however, a few degrees for a fuppofed maximum of tanning principle, which I reckon twenty.

\section{SCALE OF BARKS.}

Bark of

Elm * - - 7

Oak, cut in winter 8

Horfe cheftnut - 6

Beech - - - 7

Willow (boughs) 8

Elder - - 4

Plum-trè - $\quad-8$

Willow (trunk) - 9

Sycamore - - 6

Birch - - 4

Cherry-tree - 8

Sallow - - -8

Mountain afh -8

Poplar + - 8

Hazel - - 9

Afh - - - - 10

Spanif cheftnut - 10

Smooth oak - - ro

Oak, cut in fpring to

Huntingdon or Lei-
Tanning principle, by hydrometer.

Tanning principle, (in grains,) from half a pint, of infufion and an ounce of folition of glue,

28

$3^{\circ}$

2, I

30

2,2

$3 I$

2,4

$3 I$

$3,0 \quad 4 I$

4,0

$5^{8}$

4,0

52

$4, \mathrm{I}$

53

4, I

54

4,2

59

4,6

4,7

59

60

6,0

76

6,3

$6 ; 6$

79

9,0

82

9,2

98

9,6

104

108

cefter willow - io

IO, $\mathrm{I}$

109

Sumach - - - I4

16,2

$15^{8}$

It is to be obferved, that the barks do not keep any refpective proportion in the quantity of gallic acid and tanning principle contained in each; which is an evidence of the

- The infufion of elm was fo loaded with mucilage that it was with difficulty I could feparate the tanning principle, or try the fpecific gravity. 
diftinetnefs of principle, and may perhaps open a new field for faving oak bark in dyeing, as the willows, fallow, afh, and others, produce a very fine black. It is alfo worthy of obervation, that the quantities of gallic acid and tanning principle do not differ in equal proportions between the winter and fpring felled oaks. This fact may lead to the difcrimination of the proper time for cutting; which is, probably, when the fap has completely filled and dilated that part of the vegetable intended for ufe. This will make a difference in the feafon of cutting oak, elm, and other trees, fhrups, \&c. Leaves fhould be taken when arrived at their full fize, and then dried under cover; for, as the tanning principle is fo foluble, and the fubftance that contains it fo thin, (in aleaf,) the dew al ne might diflolve it.

Finally, as the gallic acid does not feem to combine with the matter of $\mathrm{fkin}$, and as its aftringency will corrugate the furface, we may, I think, conclude, that its prefence in tanning is not only ufelefs, but detrimental.

IV. Extrakt of a Memoir on the Grecian Metbod of dyeing Cotton Yarn Red. By C. FELIX *.

$\mathrm{T}$

HAT beautiful red dye given to cotton in the Ottoman empire, is known in Europe under the name of Turkey red, Levant red, or Adrianople red. As it is believed among us that this colour refults chiefly from the proceffes employed in the dyeing, I thall give an account of thofe followed in the Grecian manufactories. It muf, however, be obferved, that in thefe manufactories the workmen dye at one time a mals of fkains weighing thirty-five occas; each occa being equal to about fifty ounces.

The firft procefs is that of cleaning the cotton, for which purpofe three leys are employed; one of foda, another of athes, and a third of lime. The cotton is thrown into a tub, and moiftened with the liquor of the three leys in equal quantities; it is then boiled in pure water, and wathed in running water.

* From the Annales de Clbimie, No. 92. 